\title{
PENGARUH PEMBELAJARAN INKUIRI TERBIMBING PADA PELAJARAN KIMIA TERHADAP KEMAMPUAN BERPIKIR KREATIF SISWA KELAS XI IPA SMAN 2 MATARAM
} Dian Nofitha Aftriani ${ }^{1}$, Muntari Muntari', Mukhtar Hari', Yunita Arian Sani Anwar ${ }^{2}$

\author{
${ }^{1}$ Mahasiswa Prodi Pendidikan Kimia, Universitas Mataram \\ ${ }^{2}$ Dosen Prodi Kimia, Universitas Mataram \\ Program Studi Pendidikan Kimia Fakultas Keguruan dan Ilmu Pendidikan \\ Universitas Mataram
}

Keperluan korespondensi, telp/fax: +6282359292003, email: novitadian250@ gmail.com

\begin{abstract}
Abstrak
Penelitian ini bertujuan untuk mengetahui ada tidaknya pengaruh yang lebih baik pembelajaran inkuiri terbimbing pada pelajaran kimia terhadap kemampuan berpikir kreatif siswa kelas XI IPA SMAN 2 Mataram. Jenis penelitian yang digunakan berupa penelitian eksperimen semu dengan desain penelitian Nonequivalent Control Group Design. Populasi dalam penelitian ini adalah seluruh siswa kelas XI IPA SMAN 2 Mataram. Pengambilan sampel dilakukan menggunakan teknikpurposive sampling yang terdiri dari siswa kelas XI IPA 5sebagai kelas eksperimen diberi perlakuan dengan model pembelajaran inkuiri terbimbing dan siswa kelas XI IPA 4 sebagai kelas kontroldiberi perlakuan dengan model pembelajaran konvensional.Teknik pengambilan data menggunakan instrumen berupa teskemampuan berpikir kreatif kimia berbentuk uraian dengan empat indikator, yaitu kemampuan berpikir lancar, luwes, orisinal dan merinci.Uji hipotesis dengan uji t-test menunjukkanthitung $(2,92)>\operatorname{ttabel}(1,67)$ pada tarafsignifikan $5 \%$ dengan derajat kebebasan $(\mathrm{dk})=$ 84, sehingga Ha diterima. Dengan demikian pembelajaran inkuiri terbimbing pada pelajaran kimia memberikan pengaruh yang lebih baik daripada pembelajaran konvensional (ceramah dan diskusi) terhadap kemampuan berpikir kreatif siswa kelas XI IPA SMAN 2 Mataram.
\end{abstract}

Kata Kunci:Pembelajaran Inkuiri terbimbing, Kemampuan Berpikir Kreatif.

\section{EFFECT OF GUIDED INQUIRI LEARNING ON CHEMICAL LESSONS ON THINKING ABILITY CREATIVE OF CLASS XI SCIENCE STUDENTS OF SMAN 2 MATARAM}

\author{
Abstract
}

This study aims to determine whether or not there is a better influence of guided inquiry learning on chemistry lessons on the creative thinking skills of the XI IPA class of SMAN 2 Mataram. The type of research used was a quasi-experimental study with the Nonequivalent Control Group Design research design. The population in this study were all students of class XI IPA at SMA 2 Mataram. Sampling was conducted using purposive sampling technique consisting of students of class XI IPA 5 as experimental class treated with guided inquiry learning models and students of class XI IPA 4 as the control class were treated with conventional learning models. Data retrieval technique uses an instrument in the form of a chemical creative thinking ability test in the form of a description with four indicators, namely the ability to think fluency, flexibility, original and elaboration. Hypothesis testing with the t-test showed that tstat $(2.92)>$ ttable $(1,67)$ at a significant level of $5 \%$ with degrees of freedom $(d k)=84$, so that Ha was accepted. Thus guided inquiry learning in chemistry lessons gives a better influence than conventional learning (lectures and discussions) on the creative thinking abilities of the XI IPA students of SMAN 2 Mataram.

Keywords: Guided Inquiry Learning, Creative Thinking Ability. 


\section{PENDAHULUAN}

Permasalahan yang ada dalam pembelajaran yang hanya menekankan pada konsep adalah membuat siswa sulit untuk mengaitkan dan menerapkan pengetahuan yang didapat ke dalam kehidupan sehari-hari. Latihan soal yang lebih menekankan pada hafalan dan mencari satu jawaban benar mengakibatkan siswa tidak terlatih untuk mencari penyelesaian masalah melalui berbagai jalan yang mungkin ditempuh. Kebosanan yang kerap dirasakan siswa mengakibatkan siswa memilih untuk menjadi pasif dan sekedar menerima jalan keluar bagi suatu permasalahan tanpa mengolah, menganalisis, mengevaluasi dan menciptakan solusi sendiri. Hal ini berakibat pada rendahnya keterampilan berpikir siswa. Padahal keterampilan berpikir, termasuk di dalamnya kemampuan berpikir tingkat tinggi, perlu untuk dilatihkan kepada siswa, terutama pada mata pelajaran yang membutuhkan pemikiran analisis dan logis.

Berdasarkan hasil observasi dan wawancara dengan guru kimia di SMAN 2 Mataram yang dilaksanakan pada tanggal 23 Oktober 2017, diketahui hasil belajar siswa untuk mata pelajaran kimia cukup rendah, dengan kriteria ketuntasan minimum (KKM) yaitu 78. Hal ini terlihat pada Tabel 1.

Tabel 1. Hasil ulangan tengah semester siswa kelas XI IPA SMAN 2 Mataram Tahun Pelajaran 2017/2018

\begin{tabular}{c|c|c|c}
\hline Kelas & $\begin{array}{c}\text { Jumlah } \\
\text { Siswa }\end{array}$ & $\begin{array}{c}\text { Nilai } \\
\text { Rata-rata }\end{array}$ & Ketuntasan \\
\hline XI IPA 1 & 40 & 59,93 & $22,5 \%$ \\
\hline XI IPA 2 & 42 & 33,12 & $0 \%$ \\
\hline XI IPA 3 & 44 & 63,02 & $29,54 \%$ \\
\hline XI IPA 4 & 44 & 63,16 & $29,54 \%$ \\
\hline XI IPA 5 & 42 & 57,32 & $26,19 \%$ \\
\hline XI IPA 6 & 44 & 56,14 & $2,27 \%$ \\
\hline XI IPA 7 & 42 & 53,46 & $4,76 \%$ \\
\hline
\end{tabular}

Sumber: Arsip Sekolah 2017

Selain itu, berdasarkan hasil observasi pada proses pembelajaran di kelas, siswa hanya memperoleh informasi dari guru tanpa mengolah informasi tersebut lebih lanjut dan tidak mengkaitkan materi dengan kehidupan seharihari. Kemampuan berpikir kreatif siswa juga masih rendah. Hal ini terlihat dari sikap mereka yang cenderung pasif ketika proses pembelajaran dan kesulitan dalam menjawab soal yang berisi analisis permasalahan. Guru lebih dominan menggunakan metode ceramah, selain itu materi yang diajarkan jarang dikaitkan aplikasi konsep dengan kehidupan sehari-hari dan lebih cenderung memberikan latihan soal yang lebih menekankan aspek pengetahuan dan pemahaman (Ningrum, 2016).

Pesatnya perkembangan ilmu pengetahuan dan teknologi, tantangan era globalisasi, terlibatnya Indonesia dalam komunitas masyarakat ekonomi Asean (MEA), menjadi tantangan terhadap institusi pendidikan. Agar mampu berperan secara bermakna pada era globalisasi sekarang ini, diperlukan kemampuanan yang lebih sesuai dengan tuntutan perkembangan zaman. Apabila pada beberapa dasawarsa yang sebelumnya dianggap cukup dengan kemampuan dasar dalam membaca, menulis, dan berhitung, maka pada abad ke-21 ini diperlukan kemampuan lain agar dapat hidup bermakna. Ini menuntut dimilikinya kreativitas atau kemampuan berpikir kreatif (Fajriah dan Asiskawati, 2015; Rohaini, dkk., 2018).

Melihat kenyataan di atas jelaslah bahwa pentingnya kemampuan berpikir kreatif dilatih pada siswa. Untuk itu, sangat perlu sekali dalam pembelajaran di sekolah dikembangkan suatu model pembelajaran yang mendukung peningkatan kemampuan berpikir kreatif siswa. Salah satu model pembelajaran yang dapat diterapkan adalah inkuiri terbimbing.

Wahyudi dan Supardi (2013) mengatakan bahwa model pembelajaran inkuiri terbimbing merupakan model-model pembelajaran yang membantu siswa untuk belajar, membantu siswa memperoleh pengetahuan dengan cara menemukan sendiri. Di dalam model ini juga tercakup penemuan makna, organisasi, dan struktur dari ide atau gagasan, sehingga secara bertahap siswa belajar bagaimana mengorganisasikan dan melakukan penelitian guna mencapai tujuan pembelajaran.

Suastra (2009) mengatakan bahwa model inkuiri terbimbing dapat dirancang penggunaannya oleh guru menurut tingkat perkembangan intelektualnya. Inkuiri terbimbing menuntut guru membimbing siswa dengan memberikan petunjuk berupa pertanyaan-pertanyan yang bersifat membimbing. Inkuiri terbimbing diperuntukkan bagi siswa-siswa yang belum berpengalaman belajar dengan pendekatan inkuiri. 


\section{Chemistry Education Practice,1 (2), 2018 - 3}

Aftriani, Muntari,Haris, Anwar

Sanjaya (2006) mengatakan langkahlangkah model inkuiri terbimbing secara umum ada 6 yaitu: orientasi, merumuskan masalah, merumuskan hipotesis, mengumpulkan data, menguji hipotesis, dan menyimpulkan. Adapun tahapan pembelajaran inkuiri menurut Trianto (2011), yang diadaptasi dari tahapan model pembelajaran inkuiri terbimbing Eggen dan Kauchak (1996) terdiri atas 6 fase, antara lain: 1. menyajikan pertanyaan atau masalah, 2. membuat hipotesis, 3. Merancang percobaan, 4. melakukan percobaan untuk memperoleh informasi, 5. mengumpulkan data dan mengolah data, dan 6. membuat kesimpulan.

Menurut Guilford (1970), mengatakan bahwa"kreativitas mengacu pada kemampuan yang menandai ciri-ciri seorang kreatif". Yakni dengan berpikir untuk mencari berbagai alternatif jawaban terhadap suatu persoalan (divergen) bukan berpikir bahwa hanya ada satu jawaban yang benar (konvergen). Selain itu Munandar (1999), mendefinisikan kreativitas adalah kemampuan yang mencerminkan kelancaran, keluwesan, dan orisinalitas dalam berpikir serta kemampuan untuk mengelaborasi suatu gagasan.Dapat disimpulkan bahwa berpikir kreatif adalah kemampuan berdasarkan data atau informasi yang tersedia, menemukan banyak kemungkinan jawaban (berpikir divergen) terhadap suatu masalah dimana penekanannya pada kuantitas, ketepatgunaan, dan beragam jawaban. Semakin banyak kemungkinan jawaban yang dapat diberikan terhadap suatu masalah maka semakin kreatif seseorang. Tentunya jawaban yang dikemukakan harus sesuai dengan masalahnya.

Kreativitas berhubungan dengan faktorfaktor kognitif dan afektif. Faktor-faktor tersebut diperlihatkan dalam ciri-ciri aptitude dan non aptitudedari kreativitas. Adapun ciri-ciri aptitude yang berhubungan dengan kognitif meliputi ciri-ciri kemampuan berpikir kreatif (aptitude) meliputi (Munandar, 1999): kemampuan berpikir lancar, luwes, orisinal dan merinci.

\section{METODE PENELITIAN}

Penelitian ini dilakukan di SMAN 2 Mataram, kegiatan penelitian ini berlangsung mulai minggu ke 2 dan ke 3 pada bulan Mei 2018 dengan jumlah populasi seluruh siswa kelas XI IPA sebanyak 298 orang. Sampel dalam penelitian ini yaitu siswa kelas XI IPA 5 yang berjumlah 42 orang dan siswa Kelas XI
IPA 4 yang berjumlah 44 orang. Teknik pengambilan sampel (sampling) yang digunakan dalam penelitian ini adalah purposive sampling. Teknik purposive samplingyaitu teknik penentuan sampel dengan pertimbangan tertentu (Sugiyono, 2013).

Jenis penelitian yang dilakukan yaitu Quasy Experimental Design atau eksperimen semu. Dalam desain ini variabel yang muncul dan kondisi eksperimen tidak bisa dikontrol secara ketat atau secara penuh. Desain penelitian yang digunakan dalam penelitian ini yaitu nonequivalent control group design, desain ini hampir sama dengan pretest-posttest control group design, hanya pada desain ini kelompok eksperimen maupun kelompok kontrol yang tidak dipilih secara random.

Variabel bebas dalam penelitian ini adalah pembelajaran menggunakan model Inkuiri Terbimbingyang diperlakukan untuk kelas eksperimen dan pembelajaran dengan model konvensional yanng diperlakukan untuk kelas kontrol. Sedangkan variabel terikat pada penelitian ini adalah kemampuan berpikir kreatif siswa.

Penelitian ini menggunakan instrumen tes kemampuan berpikir kreatif berbentuk uraian dengan empat indikator, yaitu kemampuan berpikir lancar, luwes, orisinal dan merinci. Instrumen yang telah disusun terlebih dahulu diuji tingkat validitasnya dengan uji validitas isi menggunakan statistik Aiken's V dan validitas butir soal menggunakan formula Product moment. Untuk menguji reabilitas instrumen menggunakan Cronbach's Alpha ( $\alpha)$. Uji hipotesis dalam penelitian ini menggunakan uji$\mathrm{t}$, yaitu t-test. Uji-t dilakukan setelah data dianalisis dengan uji normalitas dan homogenitasnya.

\section{HASIL DAN PEMBAHASAN}

Penelitian ini bertujuan untuk mengetahui ada tidaknya pengaruh model pembelajaran Inkuiri Terbimbing pada pelajaran kimia terhadap kemampuan berpikir kreatif siswa kelas XI IPA SMAN 2 Mataram. Kemampuan yang diukur adalah kemampuan berpikir kraetif yang terdiri dari empat indikator. Tes kemampuan berpikir kreatif diberikan sesudah perlakuan. Instrumen menggunakan 9 soal kemampuan pemecahan masalah yang sudah divalidasi. Data tentang hasil kemampuan peserta didik sesudah perlakuan diperoleh melalui posttest. Secara terperinci terkait 


\section{Chemistry Education Practice,1 (2), 2018 - 4}

Aftriani, Muntari,Haris, Anwar

hubungan nilai rata-rata, nilai tertinggi, nilai terendah dan ketuntasan klasikal dapat dilihat pada tabel berikut.

Tabel 2. Perbandingan nilai kelas eksperimen dan kontrol

\begin{tabular}{l|c|c}
\hline \multicolumn{1}{c|}{ Kelas } & $\begin{array}{c}\text { Kelas } \\
\text { Eksperimen }\end{array}$ & $\begin{array}{c}\text { Kelas } \\
\text { Kontrol }\end{array}$ \\
\hline Nilai Tertinggi & 93 & 87 \\
\hline Nilai Terendah & 30 & 22 \\
\hline Rata-rata & 61,67 & 52,61 \\
\hline $\begin{array}{l}\text { KetuntasanKlasikal } \\
(\%)\end{array}$ & 16,67 & 6,81 \\
\hline \multicolumn{2}{|l}{ terlihat }
\end{tabular}
tertinggi, nilai terendah, nilai rata-rata, dan ketuntasan klasikal kelas eksperimen lebih tinggi dibandingkan kelas kontrol. Berikutnya dari hasil perhitungan posttest kemampuan berpikir kreatif (KBK) siswa tiap-tiap indikator berpikir kreatif (IBK), didapatkan nilai rata-rata untuk IBK-1 sampai dengan IBK-4 pada kelas eksperimen dan kelas kontrol, dapat digambarkan pada grafik berikut:

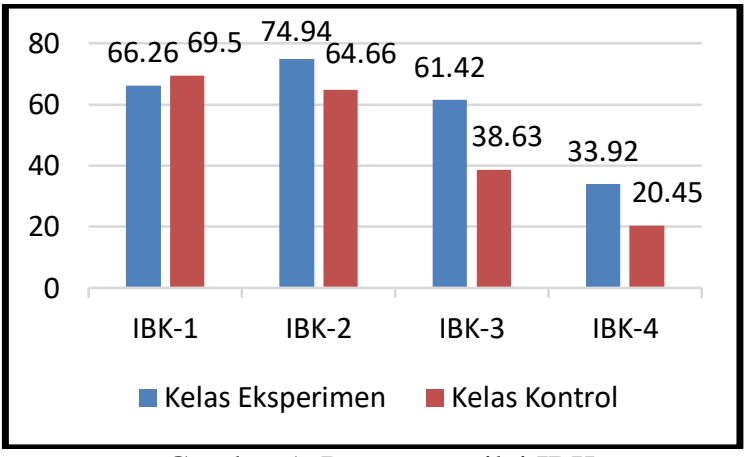

Gambar 1. Persenase nilai IBK

Pada Gambar 1 terlihat bahwa persentase nilai IBK-2, IBK-3 dan IBK-4 kelas eksperimen lebih tinggi daripada kelas kontrol, sedangkan pada IBK-1 kelas kontrol yang memperoleh nilai yang lebih tinggi. Selain itu, dapat dilihat juga bahwa pada kemampuan berpikir lancar dan luwes kelas eksperimen mendapatkan kategori yang sama dengan kelas kontrol, sedangkan pada kemampuan berpikir orisinal dan merinci kelas eksperimen lebih kreatif daripada kelas kontrol. Secara keseluruhan, kemampuan berpikir kreatif kelas eksperimen lebih kreatif daripada kelas kontrol.

Peneliti dapat mengatakan bahwa keberhasilan pada penelitian ini, disebabkan oleh beberapa faktor. Pertama, dapat disebabkan oleh proses pembelajaran yang berlangsung pada kedua kelas. Proses pembelajaran di kelas eksperimen, siswa diberi suatu pertanyaan yang berkaitan dengan materi sistem koloid. Pertanyaan yang disajikan tersebut kemudian diselesaikan melalui kegiatan praktikum dengan bimbingan guru. Kegiatan praktikum yang dilaksanakan bertujuan untuk menemukan teori, sehingga konsep dapat ditemukan sendiri oleh siswa berdasarkan hasil praktikum dengan bimbingan guru.

Kedua, dapat disebabkan oleh aktivitas siswa selama proses pembelajaran. Peningkatan kemampuan berpikir kreatif pada kelas eksperimen dapat terlihat ketika proses belajar mengajar berlangsung, siswa pada kelas eksperimen yang diberi perlakuan dengan pembelajaran praktikum berbasis inkuiri terbimbing yang menekan pada aktifitas siswa secara maksimal, siswa itu sendiri yang berperan aktif sebagai subyek belajar untuk membuat hipotesis sendiri, mengamati, menemukan, hingga memberi kesimpulan teoritis yang jelas dengan mengemukakan bukti yang menunjang dari apa yang dipertanyakannya. Pembelajaran inkuiri terbimbing dengan metode praktikum dapat membentuk dan mengembangkan self consept pada diri siswa sehingga siswa dapat mengerti tentang konsep dasar dan ide-ide lebih baik yang berakibat pada peningkatan hasil belajar siswa yang cukup baik.

Penentuan jenis uji-t yang digunakan terlebih dahulu diawali dari pengujian homogenitas data dan normalitas posttest. Uji normalitas dalam penelitian ini menggunakan rumus chi kuadrat. Berdasarkan hasil perhitungan, menunjukkan bahwa data terdistribusi normal dimana untuk kelas eksperimen dan kelas kontrol nilai $\chi_{\text {hitung }}{ }$ sebesar 5,296 dan 3,869 sedangkan $\chi^{2}$ Tabel sebesar 11,070. Hasil tersebut menunjukkan bahwa $\chi 2$ hitung $<\chi 2$ Tabel yang berarti data hasil uji normalitas pada kedua kelas terdistribusi normal. Uji homogenitas varians dalam penelitian ini menggunakan rumus uji-F. Berdasarkan perhitungan menggunakan data nilai pretest diperoleh bahwa Fhitung < Ftabel yaitu $1,04<1,68$, maka varians kedua data dikatakan homogen.

Uji prasyarat hipotesa telah dianalisis selanjutnya dilakukan uji hipotesis. Uji hipotesis yang digunakan adalah uji statistik parametrik yaitu uji-t (t-test), dengan pengambilan keputusan bedasarkan pada hipotesis statistik yang diuji sebagai berikut:

$\mathrm{H}_{0}: \mu$ eksperimen $<\mu$ kontrol

Ha: $\mu$ eksperimen $>\mu$ kontrol 


\section{Chemistry Education Practice,1 (2), 2018 - 5}

Aftriani, Muntari,Haris, Anwar

Berdasarkan hasil perhitungan diperoleh nilai thitung $(2,92)>$ ttabel $(1,67)$. pada taraf signifikan 5\%. Dari hasil perhitungan statistik tersebut menunjukkan bahwa menerima hipotesis alternatif $(\mathrm{Ha})$ yang menyatakan bahwa pembelajaran Inkuiri Terbimbing pada pelajaran kimia memberikan pengaruh yang lebih baik daripada model konvensional (ceramah dan diskusi) terhadap kemampuan berpikir kreatif siswa kelas XI IPA SMAN 2 Mataram.

Secara keseluruhan, dapat dikatakan bahwa indikator kemampuan berpikir kreatif kelas eksperimen lebih baik daripada kelas kontrol. Indikator pertama yaitu kemampuan berpikir lancar. Pada indikator ini, diharapkan siswa mampu menjawab dengan sejumlah jawaban jika ada pertanyaan atau dapat mencetuskan banyak gagasan yang relevan. Berdasarkan hasil tes, terlihat bahwa ada perbedaan jawaban antara kedua kelas. Meskipun demikian, hasil tes menunjukkan bahwa kedua kelas berada pada kategori yang sama (kreatif) untuk indikator ini, hal ini disebabkan siswa kedua kelas sudah mampu menjawab soal dengan banyak gagasan. Berpikir lancar (fluency) dalam berpikir kreatif mengacu pada keberagaman (bermacam-macam) jawaban masalah yang dibuat siswa dengan benar.

Indikator kedua yaitu kemampuan berpikir luwes. Pada indikator ini, diharapkan siswa mampu menggolongkan hal-hal menurut pembagian (kategori) yang berbeda-beda. Pada kelas eksperimen maupun kelas kontrol berada pada kriteria yang sama yaitu kreatif. Proses pembelajaran pada kelas eksperimen dapat menumbuhkan kemampuan berpikir kreatif siswa pada indikator ini, hal ini dikarenakan pembelajaran pada kelas eksperimen dengan tahapan pembelajaran seperti mengumpulkan data dapat melatih siswa untuk menentukan atau menggolongkan informasi atau data yang dibutuhkan sesuai dengan soal yang ada.

Indikator ketiga yaitu kemampuan berpikir orisinal. Pada indikator ini, diharapkan siswa mampu memiliki cara berpikir yang lain dari yang lain. cara berpikir yang lain dari yang lain. Kelas eksperimen lebih kreatif daripada kelas kontrol, yaitu kelas eksperimen berada pada kriteria kreatif sedangkan kelas kontrol berada pada kriteria kurang kreatif. Proses pembelajaran pada kelas eksperimen dapat menumbuhkan kemampuan berpikir kreatif siswa pada indikator ini, hal ini dikarenakan pembelajaran pada kelas eksperimen dengan tahapan pembelajaran seperti merumuskan kesimpulan dapat melatih siswa memberikan penjelasan sederhana. Siswa pada kelas eksperimen sudah mampu memberikan penjelasan sederhana terkait dengan pertanyaan yang diberikan, sedangkan siswa pada kelas kontrol sudah bisa menjawab tetapi belum mampu untuk menjawab sesuai yang diharapkan.

Indikator keempat yaitu kemampuan berpikir merinci. Pada indikator ini, diharapkan siswa mampu mencari arti yang lebih mendalam terhadap jawaban atau pemecahan masalah dengan melakukan langkah-langkah yang terperinci. Pada kelas eksperimen lebih kreatif daripada kelas kontrol, yaitu kelas eksperimen berada pada kriteria kurang kreatif sedangkan kelas kontrol berada pada kriteria tidak kreatif. Hal ini berarti bahwa pada kelas eksperimen siswa lebih mampu mencari arti yang lebih mendalam terhadap jawaban. Proses pembelajaran pada kelas eksperimen dapat menumbuhkan kemampuan berpikir kreatif siswa pada indikator ini, hal ini dikarenakan pembelajaran pada kelas eksperimen dengan tahapan pembelajaran seperti menguji hipotesis dapat melatih siswa untuk berpikir lain dari yang lain.

Hasil ini, sejalan dengan penelitian yang dilakukan oleh oleh Idrisah (2014) tentang pengaruh model pembelajaran inkuiri terhadap kemampuan berpikir kreatif siswa pada materi hidrolisis garam, menunjukan bahwa terdapat pengaruh yang signifikan penggunaan model pembelajaran inkuiri terhadap kemampuan berpikir kreatif siswa, hal tersebut dikarenakan pembelajaran dengan inkuiri terbimbing tidak hanya sebatas pada kegiatan mendengarkan, tetapi juga terlibat langsung dalam kegiatan mengatakandan melakukan. Selain itu, hasil penelitian ini sesuai dengan yang dilakukan oleh Tatag (2005) tentang upaya meningkatkan kemampuan berpikir kreatif siswa melalui pengajuan masalah, menunjukkan bahwa tidak semua aspek (indikator) mengalami peningkatan. Hal ini dapat dilihat, bahwa tidak semua indikator berada dalam kategori kreatif. Hal ini dapat disebabkan oleh faktor - faktor yang lain.

\section{KESIMPULAN}

Berdasarkan hasil penelitian dan pembahasan, dapat disimpulkan bahwa penerapan pembelajaran inkuiri terbimbing pada pelajaran kimia memberikan pengaruh yang 


\section{Chemistry Education Practice,1 (2), 2018 - 6}

Aftriani, Muntari,Haris, Anwar

lebih baik daripada pembelajaran konvensional terhadap kemampuan berpikir kreatif siswa kelas XI IPA SMAN 2 Mataram.

\section{SARAN}

Berdasarkan penelitian yang sudah dilakukan, peneliti mengajukan beberapa saran, diantaranya kepada guru diharapkan dapat mempertimbangkan penggunaan model pembelajaran inkuiri terbimbing dibandingkan model konvensional dalam pembelajaran pada materi sistem koloid karena berdasarkan hasil penelitian yang sudah dilakukan ternyata dapat memberikan hasil yang lebih baik, dan kepada mahasiswa (calon guru kimia) agar dapat meneliti lebih lanjut dengan menggunakan model pembelajaran inkuiri terbimbing pada materi yang lain dengan memperhatikan karakter siswa dan faktor-faktor lain yang berpengaruh terhadap kemampuan berpikir kreatif siswa sehingga dapat lebih menyempurnakan penelitian sebelumnya.

\section{DAFTAR PUSTAKA}

Fajriah, N. \& Asiskawati, E. 2015. Kemampuan Berpikir Kreatif Siswa Dalam Pembelajaran Matematika Menggunakan Pendekatan Pendidikan Matematika Realistik Di SMP.Jurnal Pendidikan Matematika. 3 (2) : 157 165.

Guilford, J. P. 1970. Creativity. America: America psychologist.

Idrisah, I. 2014. Pengaruh Model Pembelajaran Inkuiri terhadap Kemampuan Berpikir Kreatif Siswa pada Materi Hidrolisis Garam. Skripsi S1. Jakarta: UIN Syarif Hidyatullah.

Munandar, U. 1999. Mengembangkan Bakat dan Kreativitas Anak Sekolah. Jakarta: PT.Gramedia Widiasarana Indonesia.

Ningrum, P. 2016. Meningkatkan Keaktifan dan Kemampuan Berpikir Kreatif melalui
Pembelajaran Inkuiri Terbimbing terhadap Hasil Belajar dan Keterampilan Proses Sains Siswa pada Materi Kelarutan dan Hasil Kali Kelarutan. Jurnal Pendidikan Kimia UNM. 2 (2) : 17-28.

Rohaini, Wildan, dan Hakim, A. 2018. Pengaruh Model Pembelajaran Kooperatif Tipe student facilitator and explaining Berbantuan Metode Demonstrasi Terhadap Hasil Belajar Kimia Pada Materi Pokok Larutan elektrolit dan Nonelektrolit Kelas X SMAN 1 Pringgarata Tahun Ajaran 2017/2018. Chemistry Education Practice, 1 (1): 15.

Sanjaya, W. 2006. Strategi Pembelajaran Berorientasi Standar Proses Pendidikan. Jakarta: Kencana.

Suastra, I. W. 2009. Pembelajaran IPA Terkini: Mendekati Siswa Dengan Lingkungan Alamiah Dan Sosial Budayanya. Singaraja: Undiksha.

Sugiyono. 2013. Metode Penelitian Pendidikan Pendekatan Kuantitatif, Kualitatif, dan $R \& D$. Bandung: Alfabeta.

Tatag, Y. E. 2005. Upaya Meningkatkan Kemampuan Berpikir Kreatif Siswa melalui Pengajuan Masalah. Jurnal Pendidikan Matematika dan Sains. 1 (1) : $1-9$.

Trianto. 2011. Mendesain Model Pembelajaran Inovatif-Progresif. Jakarta: Kencana.

Wahyudi, L. E., \& Supardi, I. Z. A. 2013. Penerapan Model Pembelajaran Inkuiri Terbimbing pada Pokok Bahasan Kalor untuk Melatihkan Keterampilan Proses Sains terhadap Hasil Belajar di SMAN 1 Sumenep. Jurnal Inovasi Pendidikan Fisika. 2 (2) : 62-65. 